http://revped.ise.ro

Print ISSN 0034-8678; Online ISSN: 2559 - 639X

\title{
INITIAL TEACHER TRAINING TO ENCOURAGE HIGHER ORDER SKILLS IN THE CLASS
}

\author{
FORMAREA CADRELOR DIDACTICE PENTRU ÎNCURAJAREA DEZVOLTĂRII \\ COMPETENŢELOR DE GÂNDIRE SUPERIOARE LA CLASĂ
}

\section{Cristina TRIPON}

\author{
Journal of Pedagogy, 2019 (1), 21 - 40 \\ https://doi.org/10.26755/RevPed/2019.1/21
}

The online version of this article can be found at: http://revped.ise.ro/category/2019-en/

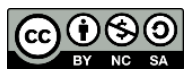

This work is licensed under the Creative Commons Attribution-NonCommercial-ShareAlike 4.0 International License.

To view a copy of this license, visit http://creativecommons.org/licenses/by-nc-sa/4.0/ or send a letter to Creative Commons, PO Box 1866, Mountain View, CA 94042, USA.

Published by:

\section{INSTITUTUL DE ȘTIINȚE ALE EDUCAȚIEI}

http://www.ise.ro/

Further information about Revista de Pedagogie - Journal of Pedagogy can be found at:

Editorial Policy: http://revped.ise.ro/editorial-policy/

Author Guidelines: http://revped.ise.ro/the-writer-guide-2/ 


\title{
INITIAL TEACHER TRAINING TO ENCOURAGE HIGHER ORDER SKILLS IN THE CLASS
}

\author{
Politehnica University of Bucharest \\ Bucharest, Romania \\ cristina.tripon@upb.ro
}

\begin{abstract}
Lifelong learning has become a necessity in most professions due to the information explosion and technology integration in daily work. Teachers, obviously, fall into this category, the teaching methods, and skills that need to be developed by students in need of continuous improvement. Changes in educational reform, too fast to adapt to children and teachers, also contribute to the daily school challenges. Ideally, the school should prepare its students for the challenges of an active life. But what happens when the labor market is still growing and the necessary skills for the future are not yet required at the current level? What happens when competencies of the 21 st century or skills in the soft-skills category are not developed by the graduates, that is, by the teachers?

This research has focused on a specially developed program, about 1 year, for future teachers. The main objective is to improve direct educational practices from the classroom by using teaching methods that encourage the development of higherlevel thinking skills.
\end{abstract}

Keywords: certification programs, high order thinking, teacher training.

\section{Rezumat}

Invă area pe tot parcursul vie ii a devenit o necesitate, în majoritatea profesiilor, datorită exploziei informa ionale şi a integrării tehnologiilor în activitatea zilnică. Profesorii, evident, se încadrează în această categorie, metodele de predare şi competen ele care necesită dezvoltate elevilor având nevoie de îmbunătă iri

* PhD., Assistant Lecturer, Teacher Training and Social Sciences Department, Politehnica University of Bucharest, Romania. 
continue. Schimbările de reformă educa ională, derulate în manieră prea rapidă pentru adaptarea copiilor, dar şi a cadrelor didactice, contribuie şi acestea la provocările zilnice şcolare. În mod ideatic, şcoala ar trebui să pregătească elevii ei pentru provocările unei vie i active. Innsă, ce se întâmplă când pia a muncii este încă în plină dezvoltare şi competen ele necesare viitorului încă nu sunt cerute la nivel actual? Ce se întâmplă când competen ele secolului 21 sau competen ele din categoria soft-skills nu sunt dezvoltate nici măcar de către cei care formează absolven ii, adică de către cadrele didactice?

Această cercetare s-a concentrat pe un program special dezvoltat, de aproximativ 1 an, pentru viitorii profesori. Obiectivul principal îl constituie îmbunătă irea practicilor educa ionale directe, de la clasă, prin utilizarea unor metode de predare care încurajează dezvoltarea competen elor de gândire superioare.

Cuvinte-cheie: competen e de gândire superioare, formarea profesorilor, programe de certificare.

\section{Introduction}

Jaime Casap, Google's representative, says in the Economist article (2018) that the job of teachers can be summed up "We have to stop asking kids what they want to be when they grow up because jobs are always changing and moving, thanks to technology. What we should be asking them is, what problem do you want to solve?"

For various reasons, education institution is mainly deeply conservative, especially in the case of mainstream education. The education system works as having the primary task of preserving and transferring the capital of knowledge to the next generation. Hirsch (1987) also invented a term that defines them, named "cultural training".

In the context of developing a competitive, knowledge-based society, the development of human capital has become a strategic priority at both European and national level. Investments in human capital development in education and training are needed to strengthen the system's ability to respond to rapid changes in society and the labor market.

In developing these skills, it is needed a complex process. This involves introducing or adopting policies to improve the quality of education and to 
ensure that learning and teaching continue to reflect the needs of individuals and society.

Educational specialists find realistically how today's school, by providing the depersonalized national curriculum and by developing the preponderance of conceptual thinking, underestimates the children's learning potential at school. We find at the curriculum, at least in the Romanian case, a series of discrepancies. The isolation of highly fragmented educational disciplines, centered on the inventory of artificial content and methodologies, is a clear symptom of the gap. In addition, there is a slight investment in teacher training, that continuing education programs for teachers to prepare them for the needs of future generations. This generally reflects the lack of unity of knowledge and holistic approaches in education.

\section{The need for professional training}

Today, the school is no longer the one that holds the monopoly in the formation of the younger generation, but its role cannot be questioned. It gets new dimensions resulting from the complex problems of the world in which we live: technology, globalization, universal communication, multiculturalism and others.

The roles and responsibilities of the teacher are diversified and nuanced in relation to new demands that come not only from the school environment, from new aspirations, new conceptions of the world and life, but also from the social environment, from the community where the school belongs. In this context, lifelong learning becomes an integral part of the continuous process of adapting the individual to the labor market. The school and, implicitly, the teachers should provide the learner (the future employee) with effective ways and strategies for a careful analysis of individual needs, effective self-organization, use of higher-level thinking skills to identify appropriate solutions in the context of various issues.

Interestingly to be analyzed is the concept of learning from a constructivist perspective. Thus, learning is the construction of reality, the creation of a world conception composed of: 
a. Our experiences and memories

b. Our networks of concepts and knowledge

c. Our perspective and our way of thinking

Consequently, constructivism explores another perspective on human learning, interpreted as a process in which the human being engages continuously and totally, both cognitively and emotionally, both as a human individual and as an exponent of a community in which he lives. Obviously, the school should adapt the learning environment to these realities in which the student (learner) finds himself permanently. Dikel (2015) expresses his contribution that the teachers are in a unique position, they are like a wheel shaft that connects different specialists (for example, school administrators, social workers, psychologists, counselors, nurses).

It is noteworthy that the emotional character of reality, the logic of affections, things that were otherwise ignored in the discussion about learning are in continuous demand. Affectivity was only taken into account in the teacher-learner relationship and much less or even not involved in the learning process.

The idea of the need for teachers with certain skills to work with learners in the context of constructivism is as real as in the present times. As we will see the role of the teacher is not a secondary one in the sense that the responsibility of the learning lies with the learner, but on the contrary, the role of the teacher becomes more and more important, the competencies of designing the contexts of learning, the management of context resources to obtain the maximum of formative effects, like the use of certain impact teaching methods. Designing, organizing, deploying and evolving activities in the constructivist context involves redefining the role of teachers, additional efforts and responsibilities, not "relieving" their tasks.

Teaching in a global approach and creating connections between different content is seen as a process that leads to new ways of thinking and learning that connect different skills, develops high-order skills and forms the "complete picture" and deeper understanding of learning. Finally, there is a basic belief that teaching with impact on learners motivates both teachers and learners, also. 
It can be considered a good teaching approach, which is obviously related to the purpose of what is considered to be "good science education". Harlen (2009) summarizes these goals as the development of scientific knowledge and the ability to learn continually, it defines scientific education as "being comfortable and competent with extensive scientific ideas, with the nature and limits of science and with the processes of science, and having the capacity to use these ideas in making decisions as an informed and preoccupied citizen."

School curricula for the gymnasium level introduced in 2017 are built in accordance with the prerogatives stated in the Law of Education (2011), article no. 2 "promoting values, creativity, cognitive capacities, volunteer capacities and capacities, fundamental knowledge and knowledge, skills and abilities of direct utility in the profession and society". One of the problems at the national level is that those teachers who are concerned about this goal did not provide (on the part of the Ministry of Education) training courses to develop these competencies to learners. Each teacher tries to find solutions for the challenge initiated by the Ministry, but according to time needs, personal financial possibilities, but poorly supported or not at all through free training courses.

\section{High-order thinking in classroom}

Facione and others (1995) describe high-order thinking as the ability to efficiently build and evaluate arguments. The skills include: a) identifying problems, b) identifying ways to address these issues, c) obtaining relevant information, d) recognizing undeclared assumptions and values, e) understanding and using the language with accuracy, clarity and differentiation, f) the evaluation of the evidence and the evaluation of the statements, g) the identification of the logical link between the sentences, h) the elaboration of the justified conclusions and generalizations, i) the testing of the generalizations and conclusions, $j$ ) the recognition of the patterns based on the personal experience, and k) the interpretation of the judgments.

Glaser (1941) believes that high-order thinking skills as a whole, implying the attitude of being open to rational approaches to problems faced by the 
subject in his personal experience, knowledge of logical and rational research methods, ability to apply these methods. High-order thinking skills require a sustained effort to examine any concept or form of knowledge, taking into account the arguments that support them and the conclusions that prefigure them.

As noted in a report, Ruggiero (2011) refers to critical thinking skills (part of high-order thinking) which consists of identifying and evaluating opinions. Critical thinking leads to reflection on the significance of the observations and the veracity of the ideas. Thinking is considered a combination of two processes. A process refers to the production of ideas (creative thinking), made by expanding perspectives and taking into account more possibilities. The second process consists of evaluating ideas (critical thinking), which consists in narrowing the perspective, sorting out the ideas that are generated, and identifying those that are reasonable.

The Delphi report (Facione, 1990) identifies the action of thinking critically as a deliberate, self-regulating judgment, resulting in interpretation, analysis, evaluation, and inference, as well as explaining the obvious, conceptual, methodological, contextual considerations, in terms of criteria bases the judgment. Critical thinking is a research and interrogation tool. It is not synonymous with efficient thinking, it is a universal, self-regulating human phenomenon. The person displaying critical thinking is usually well informed, confident in his own judgments, flexible, correct in his assessment, honest in his own difficulties, prudent in the elaboration of judgments, open to the rethinking of the statements, ordered in the complexity of situations, able to collect only relevant information, moderate in the selection of criteria, persistent in obtaining results that are accurate regarding the subject and the assessed situations. It combines the development of critical thinking skills with useful insights that are the basis of a democratic and logical society.

Starkey (2004) describes as actions of higher thinking, the ability to make observations, to be curious, to ask relevant questions and to find the resources you need, the ability to examine beliefs, assumptions and opinions against facts, recognize and define problems, the ability to access the validity of statements and arguments, the ability to make wise decisions and find appropriate solutions, the ability to understand logic and logical reasoning. 
Marzano and collaborators (2001) argue that superior thinking operations involve actions such as argumentation, prospective analysis, comparison, and others.

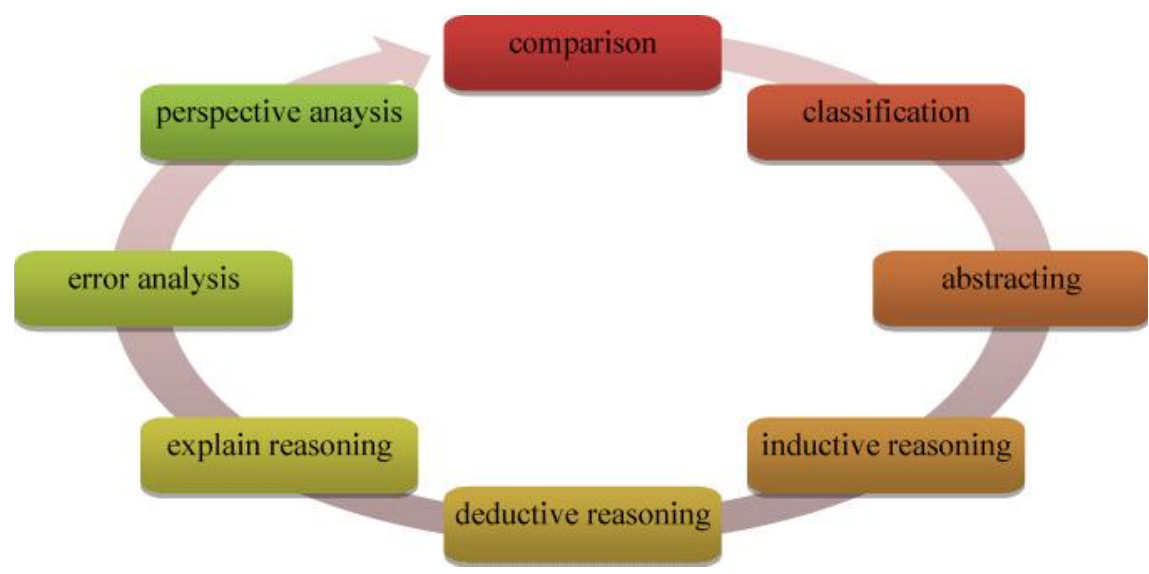

Figure no. 1. High- order thinking operations

In the sense of the work and organization of the development activities of higher-level thinking, we define it as a cognitive capacity involving the conscious participation of the person in the process of improving a decision in the direction, resulting in the analysis, interpretation, evaluation and explanation of the considerations on the basis of which reasoning is based.

In the context described, it is imperative to develop the thinking and adaptation skills to develop a sustainable future of creativity, develop decision-making exercises, develop teamwork, collaborate, develop information processing strategies, and recognize their potential for creating new ways of working through the restructuring of school curricula, working methods in the class as well as the entire learning experiences offered in educational institutions. Education learners must become active citizens of society, be prepared to solve real-life problems (not just those within the "micro-society" of lessons) through interdisciplinary and transdisciplinary training, by developing critical thinking, by developing effective communication skills, the development of social and emotional abilities that helps people to live and work together, etc. Such an investment in 
education, if we look at it in the cyclical spirit, would return to society in the form of citizens who participate effectively and innovatively in the economic development of the country.

\section{Teaching methods in high-order thinking}

In addressing teacher training issues, a variety of methods and exercises in the classroom can be developed for the development of high-order thinking, clearly tailored to the learners' needs, pace, and openness to experimentation. Some of these methods may also become evaluation methods, depending on the context of the application of the methods themselves and the objectives set. Some of these methods are used in the examples of good practice, which we explain in the following.

The method of debate is one that is highly used to develop the skills to build valid arguments in support of ideas supported by a group. Usually, in teaching, it is used in small groups of learners, to be easier to moderate and debated. The groups are organized according to the preference or support of some events, ideas to convince an audience. Such exercises develop learners' ability to explore and understand other views to develop their communication skills, to think critically, to systematically analyze other arguments in order to develop ideas of counter-argumentation.

Bloom cards and task cards (Imagine no. 1. Task-cards) are extremely versatile teaching methods for use in training courses. There are many ways to adapt the method, depending on the goals of the training. The main strengths of its use lie in its ability to use, in a practical way, efficient ways of manipulating information. Thus, whether we are talking about practical activities, needs analysis, comparisons, content analysis, in small or individual groups, the method respects the individual/group work pace, depending on the complexity of the task on the cards. In organizing workloads of the training program, the cards were developed using Benjamin Bloom's (1956) taxonomy and revised by Anderson and Krathwohl (2001) but adapted using the strategies described by Kagan (2005). Ciardiello (1998) argued that the use of card-tasks offers multiple options for exploration and skill development, being a deliberate way to attract the attention of learners through the ease of manipulation of content, through immediate attention 
centered on real objects), by the attractiveness of the materials.

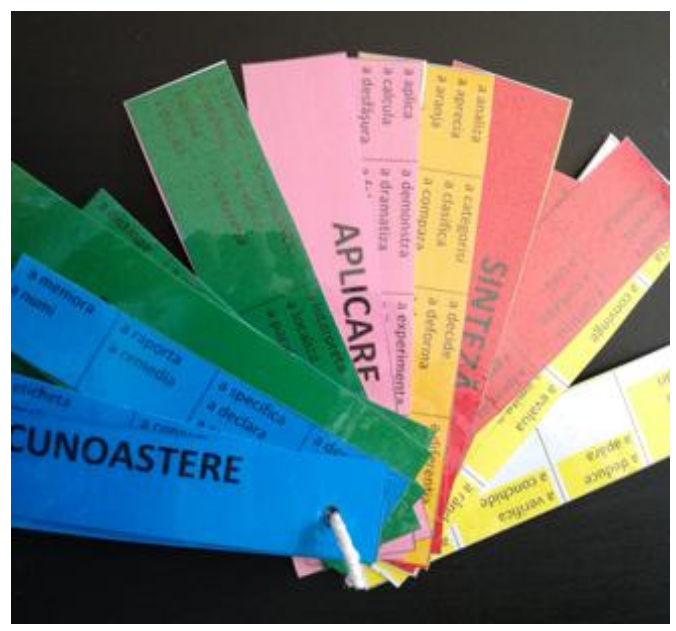

Imagine no. 1. Task-cards

Bailey and Pransky (2014), Gillies and Boyle (2010) argue that cooperative learning has great valences for long-term learning for learners. Along with the practical use of certain content, organizing in teams or in restricted groups simulates real adult life. Learners go through the process of developing common goals, assuming and empowering, by going through important stages that only together can bring about the realization of a common product. Thus, the interaction in front of the team, the interdependence of the tasks in relation to the other team members, the adaptation of behaviors and attitudes towards other teammates, the processing of the obtained results and their refinement in order to achieve the common goal, the increase of the motivation, the solving of the conflicts within the team, the interpersonal and intrapersonal development, along with high-order thinking, are just some of the advantages of using such a method in the classroom. Of course, there is a need for classroom management and the setting of rules for such activities, but this can easily be done as long as the teacher is aware of the benefits he has gained (both for himself and for those in the classroom, the students). 
Corners: The trainer sticks answers to each corner of the room. When a question is posed, learners go to a corner and discuss their answer with others who made the same choice.

Experts: Groups are doping research upon a subject (all becoming experts in their topic). Next, mix them up and the experts share the information learned.

Quiz and find: Participants write a question they don't know about a topic on a slip of paper. They must also try and answer questions.

Rally Robin discussion teaching strategies: In pairs, participants discuss a topic, talking one at a time-it turn. It is helpful to have a subject that can be passed.

!? method: Learners read a text and mark! for a piece of new information, and use for puzzling bits and information. After this stage, in groups, information marked with "!" and "?" is discussed and solved.

The Fishbone Diagram is used to analyze the causes and effects that led to the occurrence of a particular problem. Whether we are talking about geography, math, social sciences or other issues, the method is very effective for developing high-order thinking in the classroom. The Ishikawa diagram is a graphical technique with many online tools, which is often used to see clearly and objectively the context of the problem to be analyzed and propose optimal solutions in accordance with its evolution over time. Thus, it is possible to explore, in general, but also specific, what has led to the current proportion of the problem in order to identify solution opportunities adaptable to the resources identified here and now (Tiann, 2012). Such use of the diagram can be visualized in Figure no. 2, on the theme of poor investment in education.

Strategic inquiry method. Changing sometimes causes uncomfortable emotions, including denial, fear, and resilience. However, the change also offers opportunities for the emergence of new ideas. The strategic question helps integrate new ideas and strategies into community development so that people can feel positive about the change.

Six types of questions are used in the strategic inquiry method, according to Chesters (2012). These go from introductory questions to more dynamic and reflective questions. These six families of questions are: 


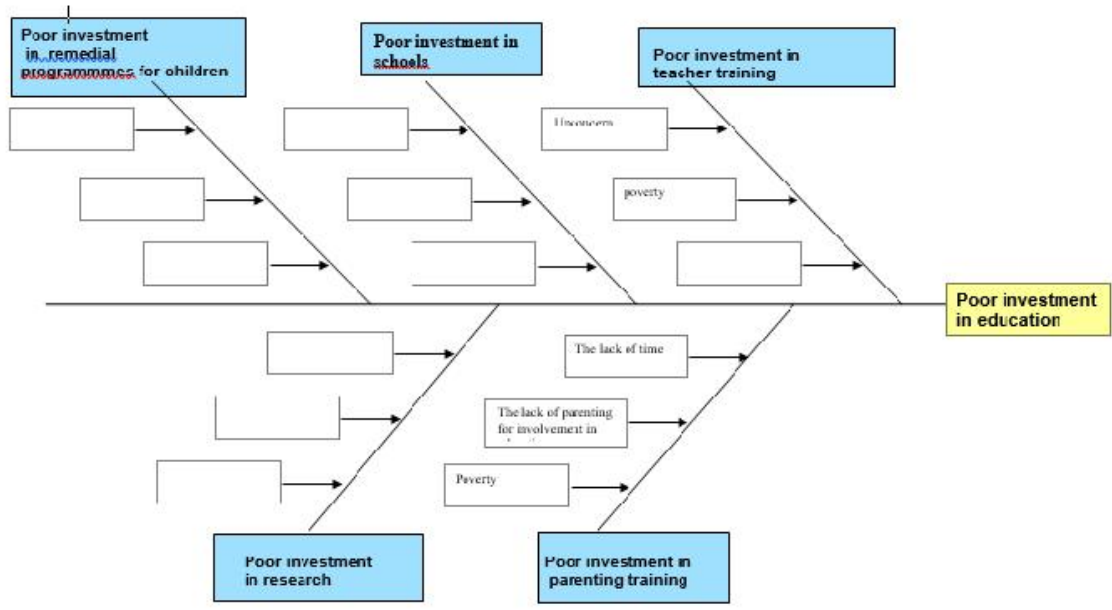

Figure no. 2. Fishbone Diagram

- Observation questions

- Feeling questions

- Watching questions

- Change your questions

- Personal inventory and support questions

- Personal Action questions

Strategic investigation helps people create their own solutions to their own problem. For example, the strategic question was used in India as a means of identifying strategies to improve water quality in the Ganges River. Locals, in partnership with the government, are developing new ways to clean the river for themselves and their children.

On the strategic question, participants usually work in pairs (with their colleague or class/team), one as a speaker and one as a "listener" to discuss a problem. According to Paul and Elder (2006), Socratic (strategic) questions can be organized as follows: 
1. Guidance questions

What do you know about the problem?

How did you find out about this?

What other people are concerned about?

How does it affect your local area?

2. Feelings / Affective questions:

How do you feel about this problem?

Did this affect your own physical or emotional well-being?

How do you feel when you think or talk about this problem?

3. Vision questions

What is the significance of this problem in your own life?

How could the situation change or how would you want it to be?

4. Change the questions

What will be required to bring the current situation to your vision?

What needs to be changed?

How could these changes occur? Name as many possibilities as possible.

5. Inventory and personal assistance questions

What should you do to be able to participate in the change?

Could your actions be helpful in bringing about these changes?

What support should you have for this change?

6. Questions about personal actions

Who do you have to talk to?

How can you get meetings with people who handle this to work on this issue?

\section{Description of the target group and research tools}

The target group of the research consists of students preparing for the teaching career within the psycho-pedagogical module, level 1. The research was conducted for one semester (6 months) during the training courses for the didactic career. The whole research group, made up of 29 future teachers, 
was tested at the beginning of the semester with the help of the test described below to analyze the level of high-order thinking skills. The group was not selected by any means, but it was organized as a third-year working party on a voluntary basis. After this stage, the whole group participated in activities designed to increase the level of high-order thinking skills, using the teaching methods described above.

The main hypothesis from which the study was developed implied that if methods such as debate, task cards, cooperative learning strategies, fishbone diagrams, the method of interrogation in training courses for the teaching career are used, the level of high-order thinking skills will increases against the initial stage (pretest time).

The Law Admission Test (LSAT), although used for admission to law schools in the USA, Canada and Australia, does not require prior knowledge in the field of law, testing only the candidates' judgment skills. In this sense, it could be used anywhere anyone wishes to verify someone else with a certain level of thinking. LSAT is divided into three sections: Analytical Thinking, Logical Reasoning and Reading Comprehension. The items in the Analytical Thinking section test the ability to penetrate into certain relationship structures and make inferences about these structures.

Items in the Logical Reasoning section test the ability to evaluate, analyze, or complete arguments. Such items are of the following types:

- Identify a premise or assumptions of an argument.

- Identify the main point of view in an argument.

- Inferences. These items test the ability to identify the conclusion of an argument (deductive or inductive).

- Identifying some argument structures. Here it is required to show the role played in an argument of a particular statement.

- Use of principles. These items test the ability to identify general rules and principles involved in reasoning and to understand their use.

- Parallel structures. These items test the ability to recognize a pattern of reasoning that is common to arguments.

- Detecting wrong arguments. These items test the ability to recognize a weakness or a mistake in an argument. 
- Parallel structures in case of wrong arguments. Items of this type test the ability to recognize a wrong model of reasoning common to arguments.

- Establish an additional test. These items test the ability to recognize which additional sample strengthens or weakens an argument.

The items in the Reading Comprehension section are centered on a larger argumentative text and test the ability to understand that text.

- Identify the main point of view, the central idea, the main idea, the main purpose.

- Items that require the use of the context to refine, specify or refine the meaning of an expression or term (the sense in context).

- Items related to the function performed by some of the author's words in a certain context.

- Another type of item refers to certain words from a passage of the text or certain implications of the passage.

- Items that require the recognition of features or patterns, analogous patterns in various other situations.

- Items related to the attitude (subjective, partisan, objective, etc.) of the author of the text.

- About the meaning of additional information.

\section{Results and discussion}

Before applying statistical tests, it is necessary to verify the normal distribution of data, both pretest and during intervention. So, we graphically display the scores of both variables in the form of histograms, then we compared the distribution of the scores with the normal distribution.

Since it is difficult to assess whether a distribution is consistent with normal distribution, we will apply a statistical test, namely Shapiro-Wilk (being stronger than the Kolmogorov-Smirnov-Field test). We run the results for both variables. 


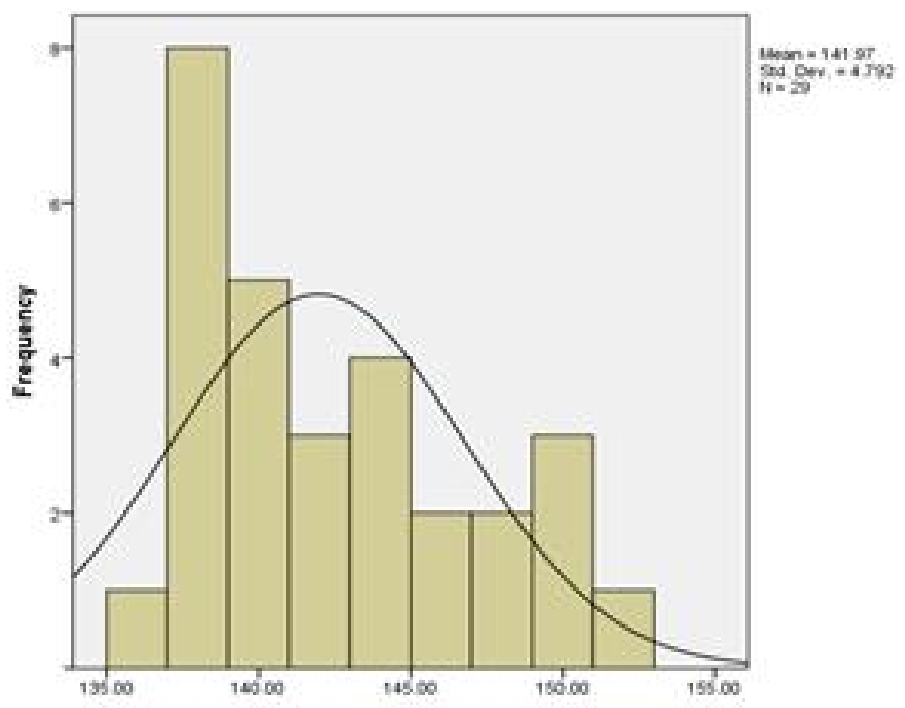

Graph no. 1. Pretest.thinking histogram

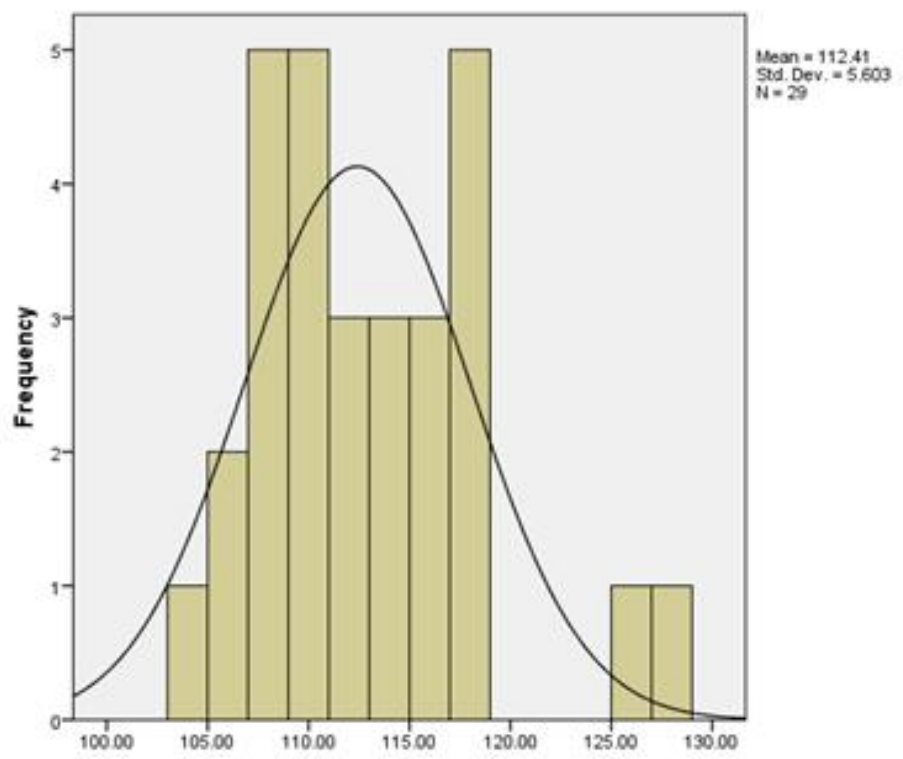

Graph no. 2. Posttest.thinking histogram 
Table no. 1. Tests of Normality

\begin{tabular}{|l|l|l|l|l|l|l|}
\hline & \multicolumn{3}{|l|}{$\begin{array}{l}\text { Kolmogorov- } \\
\text { Smirnov }\end{array}$} & \multicolumn{3}{l|}{ Shapiro-Wilk } \\
\cline { 2 - 7 } & Statistic & df & Sig. & Statistic & df. & Sig. \\
\hline pretest.thinking & .146 & 29 & .118 & .907 & 29 & .015 \\
\hline posttest.thinking & .115 & 29 & .200 & .922 & 29 & .034 \\
\hline
\end{tabular}

The Tests of Normality table shows the results of the Shapiro-Wilk and Kolmogorov-Smirnov tests; they must be statistically insignificant ( $p>0.05$ ), so that the variable is normally distributed in the population. We note that the result in the K-S test is $0.146, p=0.118$ and the result in the S-W test is $0.907, p=0.015$. As the results on both tests are not statistically significant, it results that the pretest. thinking the variable is not normally distributed. For posttest.thinking, K-S test result $=0.115, \mathrm{p}=0.200$ and the result for $\mathrm{S}-\mathrm{W}$ test is $0.922, \mathrm{p}=0.034$. As the results in both tests are not statistically significant, it results that the posttest. thinking the variable is not normally distributed.

Table no. 2. Ranks

\begin{tabular}{|l|l|l|l|l|}
\hline \multicolumn{2}{|l|}{} & N & $\begin{array}{l}\text { Mean } \\
\text { Rank }\end{array}$ & $\begin{array}{l}\text { Sum of } \\
\text { Ranks }\end{array}$ \\
\hline $\begin{array}{l}\text { Pretest.thinking- } \\
\text { Posttest.thinking }\end{array}$ & $\begin{array}{l}\text { Negative Ranks } \\
\text { Positive Ranks } \\
\text { Total }\end{array}$ & $\begin{array}{l}0 \mathrm{a} \\
29 \mathrm{~b}\end{array}$ & .00 & .00 \\
$0 \mathrm{c}$ & 29.00 & 435.00 \\
& 29 & & \\
\hline $\begin{array}{l}\text { a. pretest.thinking < postest.thinking } \\
\text { b. pretest.thinking > posttest.thinking } \\
\text { c. pretest.thinking = posttest.thinking }\end{array}$ & & \\
\hline
\end{tabular}


Since the results obtained in testing the normality of the data distribution revealed that they are not normally distributed, it is necessary to apply non-parametric tests. In this case, we will apply the non-parametric test for pairs.

The Ranks Table presents the average of rankings, the sum of rank and the number of subjects for each of the three comparison situations: negative ranks, positive ranks ( 29 cases where the rank of the posttest is higher than the rank of the pretest) and the equality situations.

Table no. 3. Test Statistics

\begin{tabular}{|l|l|}
\hline & $\begin{array}{l}\text { Pretest.thinking- } \\
\text { Posttest.thinking }\end{array}$ \\
\hline $\mathrm{Z}$ & $-4.705 \mathrm{~b}$ \\
Asymp. Sig. (2-tailed) & .001 \\
\hline $\begin{array}{l}\text { a. Wilcoxon Signed Ranks Test } \\
\text { b. Based on negative ranks. }\end{array}$ \\
\hline
\end{tabular}

The Test Statistics table shows the results of the comparison test. As $\mathrm{Z}=$ $-4.705 b, p=0.001$, there are significant differences between the level of development of high-order thinking skills measured before the intervention and those measured after the intervention. To see the meaning of the difference, we analyze the values in the Sum of Ranks column in the Ranks table, and we will report the sum of the highest ranks. In our case, the high value is 435.00 and corresponds to the positive ranks, i.e. situations where the ranges of the posttest are higher than the pretest (after and before the ranks).

We also calculate the magnitude of the effect and the median values for each of the two pair variables.

To verify whether the high-order thinking competence of the tested subjects is more developed after the intervention, compared to the previous situation we applied the Wilcoxon test. The results indicate that the experimental intervention the developed activities had a significant effect, resulting in 
significant differences between the posttest and pretest variables, $\mathrm{z}=-4.705$ $\mathrm{p}=0.001$, the analyzed competences being more developed after the intervention. The magnitude of the effect is $r=0.760$, which shows a strong effect of the experimental intervention on the development of high-order thinking competence with the help of the LSAT test, which means that we reject the null hypothesis and accept the one stated in the first part of the paper scientific.

\section{Conclusion}

In conclusion, we can say that the research hypothesis has been fulfilled. The experimental group of subjects was evaluated after participating in the training activities, the results obtained having the magnitude of the effect $r=0.760$, which shows a strong effect of the experimental intervention on the development of high-order thinking competence with the help of the LSAT test, which means that we reject the null hypothesis and accept the one given in the first part of the scientific paper.

The main objective of the research was to develop the improvement of the educational practices by using in the classroom the methods that develop superior thinking skills. In the $21^{\text {st }}$ century, if we analyze national and international reports, from the perspective of looking at the needs of labor market and from the perspective of changing skills, we realise how important it is for school, this means teachers and activities, to promote easy integration competencies for students. This is not easy, given that education in Romania receives a 3\% investment, as its own legislation (6\%) is not respected. Teacher training is done sporadically, with significant syncope, as educational pseudo-reforms are being introduced at a rapid pace. Investing in teacher training to develop innovative citizens, able to take risks, be responsible in the community, and develop solutions tailored to their needs. Introducing such courses in initial teacher training is imperative here and now if we want sustainable learning.

\section{References}

- Anderson, L.W., \& Krathwohl, D.R. (2001). A taxonomy for teaching, learning, 
and assessing: A revision of Bloom's taxonomy of educational objectives. New York, NY: Longman.

- Bailey, F., \& Pransky, K. (2014). Memory at work in the classroom: Strategies to help underachieving students. Alexandria, VA: ASCD.

- Bloom, B.S. (1956). Taxonomy of educational objectives: The classification of educational goals. New York: Longmans, Green.

- Chesters, S. D. (2012). The Socratic Classroom: Reflective Thinking Through Collaborative Inquiry. New York: Sense Publishers.

- Ciardiello, A.V. (1998). Did you ask a good question today? Alternative cognitive and metacognitive strategies. Journal of Adolescent \& Adult Literacy, 42(3), 210-219.

- Dikel, W. (2015). Sănătatea mentală a elevului. Ghid pentru personalul didactic. Bucureşti: Editura Trei.

- Facione, P.A. (1990). Critical Thinking: a Statement of Expert Consensus for Purposes of educational Assessment and Instruction, Executive Summary, "The Delphi Report", Millbrae, CA: The California Academic Press.

- Facione, P.A., Sanchez, C.A., Facione, N.C., \& Gainen, J. (1995). The disposition toward critical thinking. Journal of General Education, 44(1), 1-25.

- Gillies, R. M., \& Boyle, M. (2010). Teachers' reflections on cooperative learning: Issues of implementation. Teaching and Teacher Education, 26(4), 933-940. https://doi.org/10.1016/j.tate.2009.10.034.

- Glaser, E.M. (1941). An experiment in the Development of Critical Thinking. Columbia: Columbia University.

- Harlen W., \& Qualter, A. (2009). The Teaching of Science in Primary Schools. New York: David Fulton Publishers.

- Hirsch, E.D. (1987). Cultural Literacy; What Every American Needs to Know. Boston: Houghton Mifflin Company.

- Kagan, S. (2005). Rethinking Thinking - Does Bloom's Taxonomy Align with Brain Science? San Clemente, CA: Kagan Publishing.

- Marzano, R.J., Pickering, D.J., \& Pollack, J. (2001). Handbook for classroom instruction that work. Alexandria, VA: ASCD ASDC.

- Paul, R., \& Elder, L. (2006). The Art of Socratic Questioning. Dillon Beach, CA: Foundation for Critical Thinking.

- Ruggiero, V. R. (2001). The art of thinking: a guide to critical and creative thought (6th ed.). New York: Longman.

- Starkey, L. (2004). Critical thinking skills success in 20 minutes a day. New York: Learning Express, LLC.

- Tiann. M. (2012). Diagram Fishbone dari Ishikawa. Retrieved from: https:// tianno.wordpress.com/2019/05/

- Worldwide Educating for the Future Index. Building tomorrow's global citizens. (2018). Yidan Prize Foundation, The Economist Intelligence Unit Limited. 
The online version of this article can be found at: http://revped.ise.ro/category/2019-en/

\section{(CC) $B Y-N C-S A$}

This work is licensed under the Creative Commons Attribution-NonCommercial-ShareAlike 4.0 International License.

To view a copy of this license, visit http://creativecommons.org/licenses/by-nc-sa/4.0/ or send a letter to Creative Commons, PO Box 1866, Mountain View, CA 94042, USA.
Versiunea online a acestui articol poate fi găsită la: http://revped.ise.ro/category/2019-ro/

\section{(cc) BV-NC-SA}

Această lucrare este licen iată sub Creative Commons Attribution-NonCommercial-ShareAlike 4.0 International License.

Pentru a vedea o copie a acestei licen e, vizita $i$ http://creativecommons.org/licenses/by-nc-sa/4.0/ sau trimite i o scrisoare către Creative Commons, PO Box 1866, Mountain View, CA 94042, SUA. 